\title{
Fichte's Practical Response to the Problem of Other Minds
}

Matthew C. Altman

\section{(2) OpenEdition \\ Journals}

Electronic version

URL: http://journals.openedition.org/ref/859

DOI: $10.4000 /$ ref.859

ISSN: 2258-014X

Publisher

EuroPhilosophie Editions

Electronic reference

Matthew C. Altman, «Fichte's Practical Response to the Problem of Other Minds », Revista de Estud(i)os sobre Fichte [Online], 16 | 2018, Online since 01 December 2018, connection on 08

September 2020. URL : http://journals.openedition.org/ref/859 ; DOI : https://doi.org/10.4000/ref.859

This text was automatically generated on 8 September 2020

(C) EuroPhilosophie 


\title{
Fichte's Practical Response to the Problem of Other Minds
}

\author{
Matthew C. Altman
}

1 In our everyday lives, there is no doubt that we have moral obligations to other people. There are those at the margins of personhood - fetuses and the severely mentally disabled, perhaps even some higher animals - but the typical person with all of his or her faculties is the paradigm case of a morally considerable being. If we pursue this further, however, we find that it is difficult to justify the attribution of mental predicates to anyone but myself. Traditionally, this has been a major issue at the intersection of epistemology and ethics, because whether we should consider someone in our moral deliberations is often thought to depend on their cognitive abilities or their capacity for consciousness.

2 According to Fichte, the problem of other minds is one of the most important questions that philosophy can address (EPW 153 [GA I/3:34]). ${ }^{1}$ For both Kant and Fichte, we have direct moral duties only to other rational beings. The fact that the other is present to us as a representation (for Kant) or as a Not-I that is posited in opposition to the I (for Fichte) threatens our supposed moral obligations to them and risks a form of metaphysical solipsism and moral egoism. The bindingness of interpersonal obligations depends on overcoming the separation between me and other persons.

Fichte claims that Kant's neglect of this problem is "the most striking demonstration of the incompleteness of Kant's Critical philosophy” (NM 303 [K 150]). What little response Kant does give is unsatisfactory. For Kant, the reality of my own freedom follows in a practical sense from my immediate sense of moral constraint, but the reality of others' freedom is unavailable to me, both theoretically and practically. Kant is left only with "marks" of rationality that correlate with but do not entail others' personhood.

By contrast, Fichte contends that the only way out of this problem is to appeal to our practical commitments. Some interpreters of Fichte have drawn upon the summons (Aufforderung) as an original, non-derivative basis on which to establish my moral obligation to others. Although the summons can establish the personhood of the other, 
and thus addresses one facet of the problem of other minds, Fichte claims that it has no distinctively moral implications.

In order to establish the other as a morally considerable being, Fichte reverses the direction of implication: I do not derive my moral duties from others' personhood; rather, others' personhood follows from my immediate sense of moral obligation toward them. The way that the problem of other minds is posed presupposes that the only appropriate answer would be a series of propositions that establishes the existence of other morally considerable beings outside of myself. The immediate moral feeling of considerability, however, is not a proposition. Fichte thus provides a radically different alternative to Kant's approach. The problem of other minds is not answered or solved but is rather dispelled in Fichte's philosophy by the feeling of moral obligation and the recognition of others as the object of our obligations.

\section{Kant on Our Ignorance of Others' Humanity}

6 Kant's transcendental idealism is innovative in its explanation of how personhood is metaphysically possible, but it is all-too-traditional in its account of how the other is epistemically available. Kant defines a person as "a subject whose actions can be imputed to him," and moral personality in particular as "the freedom of a rational being under moral laws" (MM 6:223). It follows that we cannot know whether there are other persons (or even whether I am a person) because we can only know things as they appear to us, things appear to us according to the concept of causality, and complete causal necessity entails universal determinism. Considered empirically, human beings are bound by the same natural laws as other things (MM 6:223).

7 If our actions were entirely determined, we would have no moral obligations. Not only would we be incapable of moral agency, but nothing and no one would be morally considerable, because only rational beings have absolute, non-instrumental value. When rational end-setters (if there is such a thing) decide to do something, they designate it as worthy of pursuit. Therefore, moral agents ought to promote the capacity to set ends, because it is a condition of things being good for them. This is the reasoning behind Kant's third formulation of the categorical imperative, the formula of humanity, which enjoins us to treat the humanity in a person always as an end in itself and never merely as a means ( $G$ 4:429). Kant equates the class of moral patients, beings to whom one has duties, with the class of moral agents - what Christina Hoff calls the "patient-agent parity thesis." 2 So, we must determine whether beings who look and behave like responsible beings are in fact agents in order to determine whether they are morally considerable.

8 Famously, Kant says that he "had to deny knowledge in order to make room for faith," meaning that limiting our knowledge to appearances implies that the reality of human freedom is not logically ruled out (Bxxx; see also A557-58/B586-87; CPrR 5:72, 94). Rational self-determination is possible if we consider ourselves apart from our epistemic conditions. However, here Kant finds himself at an impasse: our epistemic limits make it impossible for me to know whether I or anyone else is a rational agent, since I can know myself and others only as appearances - in inner sense and outer sense, respectively. Yet my moral obligations extend only to those who are rational agents. Other minds thus pose a problem for Kant that is even more radical than the original problem: I cannot even know (theoretically) that I am free, so I can't know if I 
am a morally considerable being. Without knowing if there are any moral agents, I cannot determine the scope of my duties or whether I am able to choose rightly or wrongly.

9 In the Kritik der reinen Vernunft, Kant shows that freedom is possible, but he concludes that I cannot know whether anyone is in fact free. It is not until the Kritik der praktischen Vernunft that he establishes the practical reality of freedom by appealing to the fact of reason. I cannot help but act with a consideration of what I ought to do, and that immediate sense of moral constraint justifies a practical commitment to my own freedom, even though I cannot know (in a theoretical sense) whether I am free (CPrR $5: 32,48,55,56)$.

10 Even if we grant that this appeal to the fact of reason works as an argument, what follows is a limited conclusion. I have a practical basis for thinking that I am a rational being, so I can justify self-regarding duties. However, I cannot know whether what appear to be other persons are conscious of their motives or experience moral constraint. In the words of Jonathan Bennett, Kant's transcendental idealism amounts to a "methodological solipsism" that "forbid[s] him to take for granted the ways in which we do - or even the fact that we do - apply mental predicates to others." I may have obligations to others, but on Kant's own terms, I have no reason to believe that they are rational beings to whom I owe such things. Kant sets this up as a matter of justification: I must warrant a commitment even to my own freedom, and I justify this commitment on practical grounds. How, then, do I warrant a commitment to others' freedom, and thus their humanity?

\section{Kant on Empirical Correlates of Free Willing}

11 Because I only have practical faith in my own freedom from the first-person perspective, I must try to establish the existence of other minds through my knowledge of them as representations. Kant only explicitly addresses this issue in the Transcendental Dialectic and in his work on anthropology, where he claims that apparent "signs [Zeichen]" (A359, A546/B574; An 7:192, 285) or "marks [Merkmale]" (Ak 25:1156) indicate that a person is rational and spontaneously self-determining. $\mathrm{H}$. Tristram Engelhardt, Carol Van Kirk, and Patrick Frierson have all appealed to these signs to defend Kant against the threat of solipsism and to justify my sense of moral obligation to others, although they have appealed to different signs that indicate different mental capabilities.

12 Frierson appeals to signs of cognition. According to Kant, free actions have motives that are based in the understanding rather than stimuli (LM 29:1014-15), so Frierson says that we should consider those beings to be free whose marks indicate the presence of higher cognitive faculties, such as the use of concepts. ${ }^{4}$ For example, the use of language, by which people express concepts, distinguishes human beings from animals that act purely on instinct: "All language is a signification of thought [Gedankenbezeichnung]" (An 7:192-93; see also 7:155). Similarly, Engelhardt argues that "one can infer from observation of the behavior (including verbal behavior) of certain objects that they are associated with phenomena of inner sense." ${ }^{5}$ For example, if someone appears to consider others and give reasons for their decisions, I then use "the psychological idea" in a regulative way to unify the phenomena as expressions of the person's inner sense, much as we use reflective judgment to unify living things as 
organisms using the idea of natural purposes. This precludes our conceiving of others merely as determined things without consciousness, and it "supplies the further extension of theoretical knowledge integral to the employment of practical reason." 6

Van Kirk takes a different approach, directly appealing to signs of moral deliberation: personhood is indicated by "the fact that the agent perceives himself as faced with a choice. ... The fact that some object gives evidence that its actions are, or could be, performed because they ought to be performed is sufficient ground for imputing to that object self-consciousness and reason." For Kant, the immediate sense of moral constraint entails that I must consider myself to be free from the practical perspective; for Van Kirk, the presence of what appears to be moral constraint in a person weighing reasons (or saying that he is weighing reasons?), struggling with inclinations (furrowing his brow?), and so on - entails that I am justified in attributing humanity to him.

\section{Problems with the Appeal to Signs}

The first response to Frierson's, Engelhardt's, and Van Kirk's interpretations of Kant's strategy is that they are not fully appreciating the problem of other minds. Solipsists readily admit that others seem to be choosing on the basis of what is morally required of them or seem to do what only rational people can do, but they deny that these signs entail the existence of a rational subject - with consciousness, humanity, higher cognitive faculties, etc. - as their cause. In fact, on Kant's own view, correlating transcendental freedom with marks of moral deliberation or higher cognition establishes nothing of moral significance. If the reality of freedom could be established based on appearances, then the existence of what seem to be free actions would be enough to establish my own moral agency. Yet Kant's theoretical philosophy only makes room for faith in freedom. The reality of freedom must be established practically, from my immediate sense of moral constraint - which is different from merely appearing to be morally constrained.

Kant is struggling here with how to approach the problem of other minds given three central pillars of his philosophy: the distinction between appearances and the thing in itself, the fact that we are transcendentally free as noumena, and his claim that the reality of freedom is established only from the first-person, practical perspective. We can say nothing positive about the thing in itself on the basis of appearances. Kant is careful not to say that we infer the reality of others' freedom by the marks of responsibility, because that would violate the epistemic restrictions that he sets out in the first Kritik. Van Kirk, Engelhardt, and Frierson accept this, but they try in different ways to overcome the limits of cognition. Van Kirk makes something like a transcendental argument from deliberation to reason: "rationality is not something that is inferred from 'the data' because there are no data regarding the moral realm unless rationality is presupposed." This is true. However, she continues: "Rationality must be assumed at the outset if a particular type of behavior is to be coherent." ${ }^{8}$ It is precisely the force of this 'must' that the solipsist rejects. The appearance that someone is engaging in moral deliberation or the secondhand claim by someone that they are bound by moral constraints does not have as its transcendental condition that they are in fact rationally self-determining because, again, that would render the fact of reason argument unnecessary. It is also not true. Apparent deliberation is not "coherent" only 
if one is actually deliberating. If it were, the problem of other minds would be nonsensical; the mere appearance of rationality would make one rational. On Van Kirk's view, someone who seems to be reasoning would already be a counterexample to solipsism. Yet Kant is no behaviorist.

16 Frierson and Engelhardt take slightly different approaches from that of Van Kirk. Frierson concedes that the marks of rationality in others cannot justify a belief in others' freedom. However, he says that they can justify our moral judgment of others in a practical sense: "for the practical purposes of determining which objects in the empirical world are agents whose empirical character is grounded in a transcendentally free intelligible character bound by the moral law, the markers ... will be both necessary and sufficient." That is, all I have is the appearance of others, and on that basis what I have is good enough to make moral judgments. They are not "metaphysically sufficient conditions for moral responsibility," but given the way that I am constituted and the fact that such marks are correlates of higher faculties in me, such marks are sufficient - in the world we inhabit, though not in every possible world - to indicate who else is free and who is not. ${ }^{10}$ Engelhardt goes beyond this to claim that use of the regulative idea, applied because of certain apparent behavior, is sufficient to justify a theoretical commitment to others' personhood ("knowledge of other persons"), and that on this basis we can derive our moral obligations to them. ${ }^{11}$

There are two problems with these arguments. First, it is wrong to construe a practical commitment to others simply as a lesser kind of theoretical commitment, or a belief with lower epistemic standards. Practical justification is different from theoretical justification; it is not a theoretical justification that is "good enough." The second, related problem is that these approaches only push the question back. If the marks of higher cognitive functions could establish freedom for practical purposes, then it would be enough to justify a practical commitment to freedom in me as well. Yet Kant's strategy in the second Kritik is different. He does not begin with theoretical claims regarding "signs," which are kinds of appearances, and move to practical commitments. Rather, a first-person, practical commitment (the 'ought') warrants a first-person, practical commitment to the reality of my own freedom. There is no doubt that, once I establish the reality of freedom in myself through the fact of reason, then I can identify correlations between my free will and my character. One could say that my behavior expresses my freedom, or even that it confirms (in some sense) freedom's practical reality. However, the empirical character cannot be used to warrant a belief in the existence of free will, either in me or in others, practically or theoretically. The problem of other minds remains.

\section{The Practical Starting Point of the Wissenschaftslehre}

Fichte's idealism diverges from Kant in significant ways, and his philosophical innovations allow him to dispel the problem of other minds rather than unsuccessfully trying to answer it, as Kant and his interpreters do. Fichte identifies a problem with the problem of other minds itself: the assumption about what would be a satisfactory answer - inference from an apparent characteristic - makes it an impossible problem to solve and depends on a conception of persons as things that are contingently related. Attempting to provide a theoretical or cognitive response to the problem already concedes too much. Fichte appeals instead to both our mutual dependence and our 
moral feelings. Despite persistent characterizations of Fichte's idealism as a form of subjectivism, one of his most significant departures from Kant is his claim that, in having moral obligations, I immediately take on a relation to others. Fichte thus responds to the problem of other minds by analyzing my practical engagement with the other, not by making a theoretical appeal to appearances.

Both the challenge of and solution to the problem of other minds are established in Fichte's metaphilosophy, where he justifies idealism by appealing to a first-person practical faith in my own freedom. With regard to first principles, Fichte believes that we are faced with a choice between two equally plausible but mutually exclusive explanations of the world: either the subject is primary and posits the object in opposition to its activity ("idealism" or "criticism") or there is nothing but inert matter governed by causal laws, so that even the subject is determined by biological and psychological events ("realism" or "dogmatism"). Fichte says that dogmatism cannot explain the unity of being and seeing, since it cannot account for the consciousness that makes representations possible (IWL 20-23 [GA I/4:195-97]), and that our immediate sense of our own freedom lends support to the idea that we are not merely causally determined things (IWL 49 [GA I/4:219]; SE 55-56 [GA I/5:64-65]). Nonetheless, he concludes that no theoretical argument could justify idealism for the dogmatist, who insists that consciousness is an epiphenomenon of material processes and that the feeling of freedom is an illusion (IWL 15-16 [GA I/4:192]; SE 56 [GA I/5:65]; NM 92-93, 98 [K 15-16, 19]). Apparent signs of free activity - the sort of evidence given by Frierson, Engelhardt, and Van Kirk - only serve as indications of the subject's freedom if we presuppose freedom at the outset.

20 Fichte resolves this impasse by saying that people with a strong sense of their own freedom are unable to conceive of themselves as mere things, and thus that they commit themselves to idealism as a kind of assertion of their own freedom: "I will to be self-sufficient, and I therefore take myself to be so. Such a taking-to-be-true, however, is faith [Glaube]. Our philosophy therefore begins with an item of faith, and it knows that it does this" (SE 31 [GA I/5:43]; see also IWL 18-19 [GA I/4:194-95]). Like Kant, Fichte claims that faith in freedom is grounded in or warranted by the immediate sense of moral constraint (IWL 49 [GA I/4:219]). ${ }^{12}$ Unlike Kant, Fichte does not think that he first needs to "make room for faith." The theoretical account of my existence and the existence of objects is secondary to and derivative from the practical demand that I be self-determining.

The ethical theory that results from the choice of idealism has autonomy as its moral ideal. The I posits the object in response to a check (Ansto $\beta)$, which means that the object is derived from the I's activity. As an embodied self, the I confronts a limitation to its activity that is also a condition of its very subjectivity, for without the object there would be no subject. The categorical imperative, then, enjoins us to produce objects of consciousness in accordance with our own self-legislated laws: we strive to achieve "absolute self-sufficiency [Selbständigkeit]" (SE 61 [GA I/5:70]) or "conformity with the pure self" (SK 230n [GA I/2:396n]) by making the world as it ought to be (see also SK 237, 239 [GA I/2:403, 404-5]; SE 219-20 [GA I/5:209]). If the external world were completely in accordance with the absolute, then there would be no distinction between subject and object, no resistance to the I's activity. Therefore, the I engages in an endless "striving [Streben]" for a moral ideal that, so long as the I is finite, it can never achieve (SK 231 [GA I/2:397]; see also SE 198-99 [GA I/5:191]). 


\section{Fichte on Our Ignorance of Others' Subjectivity}

On this view, the appearance of other people is due to the activity of my understanding, with which I posit things according to certain rules. Fichte is conceding that idealism poses a special problem that Kant has failed to answer. He rejects the appeal to "signs which distinguish [Unterscheidungszeichen] rational beings from nonrational ones ... derived from experience," because even the "egoist" recognizes such signs without granting that they are evidence of others' personhood (EPW 154 [GA I/3:34]). Fichte concludes that theoretical reason has no adequate response to solipsism: "The most that experience can teach us is that there are effects which resemble the effects of rational causes. It cannot, however, teach us that the causes in question actually exist as rational beings in themselves" (EPW 154 [GA I/3:35]). Even if they look or act as I do, no inference can be made from the appearances of others ("signs") to their selfconsciousness or their humanity. If the problem of other minds is to be adequately addressed, it "must be answered on the basis of practical principles" (EPW 154 [GA I/ 3:35]). There is an apparent parallel here to the dogmatism/idealism divide: there is no theoretical argument that will decide the matter, which gives us a sense of the limits of theoretical reason and the need to call on other resources.

\section{"No Thou, no I": The Aufforderung}

Fichte's first innovation relevant to the problem of other minds is his doctrine of the summons. He dispels the problem, in part, by establishing my practical engagement with others as necessary for my existence as a person and an individual. However, because of Fichte's strict distinction between rights and moral obligations, the summons has only limited implications: although the summons establishes the other as 
a subject, and thus overcomes metaphysical solipsism, it does not establish my moral obligations to them, leaving ethical solipsism - or perhaps ethical egoism, the idea that my moral obligations are merely self-regarding - intact.

My relation to the other emerges in the context of my ability to affect the world through my actions. Specifically, my subjectivity depends on another rational being issuing a "summons [Aufforderung] to self-activity" (SE 209 [GA I/5:201]). Fichte explains the process in detail in the Grundlage des Naturrechts (FNR 29-39 [GA I/3:340-48]). He begins by saying that, to be a "person," I must be free in a formal sense, which he defines as the ability to set ends and to act on my concept of them to cause changes in the world: formal freedom is "absolute spontaneity" in "the act of forming the concept of an intended efficacy outside us, or the concept of an end [Zweck]" (FNR 9, 20, 53 [GA I/3:319, 331, 361]; see also FNR 48 [GA I/3:357]). ${ }^{14}$ In addition, to be an "individual," I must not only have formal freedom but must be conscious of myself as a discrete source of effective agency, set apart from others (FNR 40 [GA I/3:349-50]).

The object becomes a representation for me through the activity of judgment (theoretical reason), and it is transformed or affected by my formally free activity (practical reason). As noted earlier, to be self-conscious, I must also separate myself from the object in consciousness, or must posit it as outside of and distinct from me as a subject. Thus the object depends on the theoretical and practical activity of the subject that posits it, but the subject also depends on its relation to the object as an independent thing (FNR 29 [GA I/3:340]). This poses a problem, since the object must be both determined in itself (to make the subject possible) and determinable through the subject (as a posited representation). In the Wissenschaftslehre nova methodo, Fichte talks about this in terms of the subject's need for a "goal [or end, Zweck]" and the fact that a goal must constrain or demand something of me, yet I must select a specific goal to pursue; I am passive in the former sense and active in the latter (NM 352 [K 177-78]).

To remove this contradiction, Fichte says that the self must become an object to itself specifically, it must be the object of self-consciousness - while also being determinable as an object (or body) through its own subjective activity. This is achieved by thinking "of the subject's being-determined as its being determined to be self-determining, i.e., as a summons to the subject, calling upon it to resolve to exercise its efficacy" (FNR 31 [GA I/3:342]). Another rational being, or "a general mass of rational beings as such" (NM 351 [K 177]), imposes a normative "demand [Anforderung]" that I exercise my freedom (FNR 33 [GA I/3:343]). For example, if someone asks me to stop hurting him, then I have to decide whether or not to stop. By responding as a self-conscious subject and deciding on a reason to act, I become responsible for what I do. As Allen Wood puts it, the summons provides "a ground or reason for doing something (for doing what we are summoned - asked, invited, required - to do)." ${ }^{15}$ Is the fact that he is hurt enough of a reason for me to stop doing what I am doing? No matter how I decide, by weighing the reasons I take on the action as my own. The other's demand gives me what may be a compelling reason to restrain myself: I should not hurt someone unnecessarily. Thus Fichte claims that the principle of right is deducible from mutual recognition: in calling on me, the summoner takes me to be a responsible agent, and in response to the summons, I "recognize [anerkennen]" him as a rational being like me (FNR 42-43 [GA I/ 3:352-54]). Like Engelhardt, Fichte says that I use reflective judgment to decide whether given effects - actions not governed solely by instinct, an expressive face, and so on can be explained only with reference to a rational cause (FNR 35-36, 76-78 [GA I/ 
3:345-46, 381-83]). ${ }^{16}$ The crucial difference is that, for Fichte, I must recognize another rational being as a condition of my own self-consciousness. Once I see the person this way, I then have a choice whether to limit the exercise of my freedom out of respect for his right not to be harmed.

Fichte notes that I can either heed or resist the summons (NM 355 [K 179]; GA IV/2:179), but in either case, I actualize my freedom. That is, if I choose to do what is demanded of me, then I limit myself through a free act of self-determination, and thus become free; and if I refuse to limit myself, then that refusal is itself a choice and an act of becoming responsible for myself: "By now proceeding contrary to the demand it is aware of and refraining from acting, it likewise chooses freely between acting and not acting" (FNR 33 [GA I/3:343]; see also NM 351-52 [K 177]). Fichte decenters the primacy of the subject in the sense that the summons of the other is inescapable and it is imposed on me from without. In response to the demand, I must make a choice, and in making a choice I assert my freedom.

By demanding something of me, the summoner is setting ends and attempting to achieve them - that is, her attempt to affect me through the summons is a purposive act (FNR 36-37, 43 [GA I/3:346, 352]). Because she has formal freedom, and because I become aware that I can affect her through my actions, I realize that I ought to respond with a corresponding limitation and restriction on my own freedom, and I engage her in a relation of right (Rechtsverhältnis). I have rights because, in acting as a rational agent, "I ascribe to myself a sphere for my freedom from which I exclude the other"; and, correlatively, I must respect her rights because I "ascribe a sphere to the other from which I exclude myself" (FNR 48 [GA I/3:357]; see also RPP 316 [GA I/3:223]; FNR 53-54 [GA I/3:361-62]). Anticipating Hegel's master-slave dialectic, Fichte says that, since my I-hood depends on the other as another subject (specifically a summoner), I would be undermining the condition for the possibility of my freedom if I were to deny her freedom and treat her merely as a thing (SE 210 [GA I/5:201-2]).

Rather than following Kant in deriving his philosophy of right from the categorical imperative (see, e.g., MM 6:214), ${ }^{17}$ Fichte attempts a transcendental deduction of the principles of right as conditions for the possibility of self-consciousness (EPW 408-9 [GA III/2:387 (no. 305)]). The summons is necessary for self-consciousness, and mutual recognition as self-conscious subjects is necessary for a relation of right. The derivation of rights proceeds as follows. Insofar as I am called upon to exercise my formal freedom and to act (or not act) in a determinate way, I must be a body in relation to other bodies (NM 457, 469 [K 233-34, 241]). The body is the will viewed from a different perspective, as a thing and the means through which I can effect change in the world, since only matter can affect matter (NM 321, 326-27, 458 [K 160, 163-64, 234]). I then posit the other as a thing opposed to consciousness, and it is this thing - the body - that makes it possible for me actually to apply the bare concept of rights in real cases. That is why Fichte begins his "deduction of the applicability of the concept of right" with the claim that "the rational being cannot posit itself as an individual that has efficacy without ascribing to itself, and thereby determining, a material body" (FNR 53 [GA I/3:361]). By apprehending myself as a limited body in relation to another body, I move from what Angelica Nuzzo calls "intellectual internal recognition" of the other to "practical external recognition" of the other in an actual relation of right. ${ }^{18}$ The body of the other is both something that I can affect through my actions and something that I am called upon to respect as the basis of the other's sphere of freedom (NM 76, 457 [K 233-34]). 
Fichte thus lists two "original rights [Urrechte]": the right over my body and the right to act freely in the world (FNR 87, 107-8 [GA I/3:390, 407-8]). A mutual relation of right follows from the intersubjective engagement that makes individuality possible, and the embodiment that follows from the commitment to myself as a free and effective agent in association with other persons.

\section{Limited Implications of the Aufforderung ${ }^{19}$}

As I have shown, Fichte establishes two points in his philosophy of right that are relevant to the problem of other minds. First, Fichte says that my existence as a (formally) free agent depends on the summons of the other. I can be a self-conscious subject only in relation to other subjects: "No Thou, no I" (SK 172-73 [GA I/2:337]; see also IWL 61 [GA I/4:229]; SE 209-10 [GA I/5:201]).

1. To be a person, I must be the addressee of a summons, and the summons is only possible if the summoner is both rational and free.

Because the existence of at least one other subject is a condition for the possibility of my self-consciousness, Fichte believes that he has given a transcendental justification for the existence of other minds. This means that metaphysical solipsism is practically dissolved.

2. In the context of this practical engagement by means of the summons, there is no real problem of other minds.

Indeed, in the Sittenlehre, Fichte says that the summons is the only compelling response to the problem of other minds: it is "the sole sufficient reason for inferring that there is a rational cause outside of us" (SE 210 [GA I/5:201]). Because my self-consciousness depends on the other, the fact that I am a subject already attests to the existence of other subjects. Therefore, the summons introduces a second-person standpoint that challenges the first-person approach to freedom (by means of the fact of reason) that Kant takes.

Stephen Darwall and Robert Williams claim that this has direct ethical implications. ${ }^{20}$ They contend that the summons establishes not merely a relation of right, but an intersubjective basis for Fichte's ethics, and specifically for our moral duties toward others.

3. The summons establishes the summoner's moral considerability, and on that basis my moral duties are established.

Darwall challenges Fichte's distinction between right and morality. He insists that the summons is a kind of reason-giving, and that to comprehend it as such is to acknowledge the authority of the other to make moral demands on me, not merely conditional rights claims. ${ }^{21}$ And Williams compares Fichte to Emmanuel Levinas in his radical disruption of a first-person appeal to reason. ${ }^{22}$ Levinas claims that the core ethical experience is the encounter with the face of the other, in which the subject finds herself responsible for the other even without having recognized the other as an alter ego. ${ }^{23}$ Similarly, for Williams's Fichte, I am morally obligated to the other simply by virtue of the fact that I am provoked by them, and this is a necessary provocation because my existence as a subject depends on my being summoned by the other.

The problem with these interpretations is that they run counter to Fichte's so-called independence or separation thesis. By the time of the Grundlage des Naturrechts, ${ }^{24}$ Fichte insists, unlike Kant, that ethics and legality have distinct foundations: "the 
philosophical doctrine of right" is "a separate science standing on its own" (FNR 11 [GA I/3:321]). As Daniel Breazeale and Frederick Neuhouser emphasize, the normative constraints that are integral to the relation of right and that are implicit in the Aufforderung are not matters of moral duty. ${ }^{25}$ Mutual recognition does establish the social character of human beings, but the resulting legal restrictions on my freedom are only binding if I commit myself to maximizing external freedom. That is, unlike moral obligations, which are unconditional, legal obligations are conditional on whether I choose to live in a community with others (RPP 314-16 [GA I/3:222-24]; NM 470-71 [K 242]). To be sure, enlightened self-interest motivates me to live with others and to form laws under which our freedom is maximized, but, because this does not follow necessarily from the nature of reason itself, the decision is "arbitrary or optional [willkürlich]" (FNR 10 [GA I/3:320]; see also FNR 11-12, 81-83 [GA I/3:321-22, 386-87]). Fichte says that my respect for others as rights-bearers is merely a matter of "theoretical consistency": knowing that the other person is like me, and knowing that I want to be treated in a certain way - I demand my rights - I am rationally compelled to treat them the same way (FNR 44 [GA I/3:353-54]; see also FNR 11 [GA I/3:321-22]; VM 78 [GA I/6:264]).

In addition, the relation of right is supposed to preserve each party's formal freedom that is, the capacity to orient ourselves according to concepts representing ends - but it does not have any specifically moral end in view. Unlike morality, the law does not universally command or prohibit particular actions; rather, it permits me to act however I want, even immorally, as long as I do so within my private sphere (FNR 50, 179 [GA I/3:359, I/4:17]). I incur properly moral obligations, by contrast, owing to a rationally mandated, not interpersonally solicited, commitment to material freedom, not formal freedom. That is, I am morally constrained to strive for autonomy, to act on the basis of a self-legislated law, so I ought to determine my ends based only on their fitness for furthering the self-sufficiency of reason. The distinctive moral demand is made by my higher self, not by the other.

\section{The Practical Commitment to Others}

39 Treating the problem of other minds as an epistemic problem inevitably lands us in solipsism, or at least risks it. A theoretical approach is bound to fail, since it begins with the assumption that the other is an object of knowledge, or merely a representation for consciousness. Kant cannot then infer the humanity of someone on the basis of apparent signs. Although Fichte's practical appeal to the summons in some sense dissolves the threat of solipsism, making the other into a formally free subject, it establishes the other merely as another consciousness, and at best another rightsbearer, rather than an object of moral obligation.

What both approaches have in common is that they begin with a commitment to others' humanity and they try to infer our ethical obligations from that. Kant moves from signs to humanity, which, by means of the formula of humanity, entails that we have other-regarding duties to them. And Darwall and Williams move from the summons to the authority to make the summons, which entails that they are rational beings to whom we have other-regarding duties. This is the typical direction of inference in the history of Western philosophy: once we establish the other's existence as a person, then we can deduce that we have moral obligations to them. 
41 Fichte's revolutionary approach upends this. Though my comprehension of the summons entails my recognition of another subject in an abstract sense, it does not address the question of how I come to recognize a specific person as someone to whom I have moral obligations. Fichte claims that the distinctively moral relationship follows not from my determination that the other is a subject, but from moral feeling. That is, I know that others are rational beings with dignity because I have duties to them; I do not have duties to them because they are rational beings.

Earlier I mentioned that the aim of morality is absolute self-sufficiency. Because I am a finite, imperfectly rational being, I cannot apprehend the moral law (as a law of pure reason) directly; instead, the law affects me through what Fichte calls my conscience (Gewissen) by means of moral feeling (SE 198 [GA I/5:190-91]; see also SE 101-5, 148, 158-68 [GA I/5:104-9, 146, 155-64]; NM 469 [K 241-42]). Conscience guides us to do what is right: as Fichte puts it, "Feeling decides [Das Gefühl entscheidet]" (SE 198 [GA I/5:190]). To be sure, I exist as a self-conscious being ("my first state") because of the summons of the other, and thus my self-consciousness "is not determined through my freedom, but through my connection with another rational being." As a moral agent, though, I am beholden only to reason: "What I become or do not become from this point on, however, depends purely and simply and completely on me alone" (SE 211 [GA I/ 5:202]). The duties that I have, including other-regarding duties, are the result of the moral drive as it expresses itself in feeling through my conscience. This is a dramatic return to the first-person perspective.

In the Sittenlehre, Fichte reminds us of the relation of right among free beings, and notes that, in response to the summons, I become "merely a rational being in general," and I relate to summoners as possible rather than actual individuals (SE 211-14 [GA I/ 5:202-4]). Fichte's reasoning here is not especially clear. He seems to be saying that the generality of the summons makes it incapable of establishing a moral relationship. The summons gets us merely to "the fact of I-hood" rather than making me "a particular rational being." The former is a "universal" limitation, not a "particular limitation" (SE 214 [GA I/5:204]). The dependence of self-consciousness on the summons may give me grounds for thinking that there is some other rational being out there, but it does not give me reason to think that this is a rational being and that is not. It entitles me to use (or offers a deduction of) the concept of "another rational being," but does not provide me with a criterion (schema) for applying it.

The problem with this interpretation is that the summons only functions as a summons if we encounter a specific other whom we recognize as a rational being with formal freedom. As noted above, Fichte lists some of the criteria we use to distinguish rational beings from things that are not rational: actions not governed solely by instinct, an expressive face, and so on (see FNR 76-78 [GA I/3:381-83]). Wood claims that Fichte is giving a schematism so that we can apply the concept of a rational cause empirically. ${ }^{26}$ Using reflective judgment, I make "the inference [Schlu $\beta$ ] to a rational cause" and I treat the person as "a particular [bestimmten] rational being," not some undifferentiated mass (FNR 36, 42 [GA I/3:346, 352]).

Perhaps a better way of understanding Fichte's notion of particularity in the Sittenlehre is in keeping with the independence thesis. What is missing in the account of the summons, which is only given with moral feeling, is genuinely moral concern, as opposed to juridical concern. Instead of merely justifying the existence of the other, which the summons does accomplish, moral feeling transforms the relationship into 
one of indebtedness and obligation rather than general permissibility regarding the movement of my body. I only need to engage them in a relation of right if I participate in a community and if they also agree to respect my rights. Even if I become a subject through another (someone must summon me), I need not consciously accept that fact or acknowledge the dignity of a particular person (I ought to respect you), so it need not make any difference to my commitments. Because of the limitation of the summons, Fichte then asks: "Can they, however, be actual for me? I.e., can I perceive them as actual beings, and if so, how can I perceive them?" (SE 212 [GA I/5:203]).

Fichte seems to be addressing an issue that is a focus of critical race theory. We can establish that others exist as conscious beings, but whether that puts any obligation on me is in some sense ultimately my decision. The notion of a "person" is a very slippery concept. Charles Mills uses the language of "subperson" to get at someone who is recognized as sharing characteristics with whites/the privileged without being recognized as a full person. ${ }^{27}$ Fichte seems to be getting at some of that same ambiguity: we think "person" is merely descriptive, something that theoretical reason could establish or that could be transcendentally derived. However, really it has normative dimensions that get established in other ways: for Fichte, through personal moral feeling, and for critical race theorists, through contingent, only semi-cognitive processes of habituation and normalization.

According to Fichte, the considerability of the other as an actual someone to whom I have distinctly ethical obligations depends on my sense of duty. That is, I feel an obligation to respect the other, and from that feeling I "infer" the existence of an actual being with humanity: "we inwardly feel that our acting is being repulsed. In this case, even our drive toward acting is limited, and from this we infer [schließen] that there is freedom outside of us" (SE 213 [GA I/5:204]; cf. FNR 36 [GA I/3:346], cited above). ${ }^{28}$ The appearance of the other as an other is secondary to the immediate, unreflective, and intimate feeling that I owe something to them, in contrast to mere objects:

There are certain points [Punkte] beyond which I should not proceed with my freedom, and this ought-not [Nichtsollen] reveals itself to me immediately. I explain to myself these points [beyond which I ought not to proceed] by appealing to the presence of other free beings and their free effects in the sensible world. (SE 214 [GA I/5:205])

Conscience is an expression of what is rationally required of me. What I discover in encountering these "points" of resistance is that reason works through both me and others as tools of the moral law to strive for a complete moral system within which we recognize one another as "member[s] of the community of rational beings" - that is, I respect the humanity in them as an end in itself and help to further their purposes (SE 244 [GA I/5:230]; see also SE 217-19 [GA I/5:208-9]).

As Wood rightly notes, the second-person perspective is not part of the foundation of Fichte's ethics, but arises only in the application of the moral law..$^{29}$ What testifies to the existence of others as moral subjects, and what obligates me to further their ends, is not their appearance, which is secondary, but the sense of obligation that I have to them. ${ }^{30}$ Fichte thus gives a practical (and specifically moral) response to the problem of other minds. Kant says that my immediate sense of moral constraint justifies a practical commitment to my own freedom; Fichte says that my immediate sense of moral obligation justifies a practical commitment to the freedom of others. 
50 Earlier I quoted a passage from the Bestimmung des Menschen in which Fichte claims that speculative philosophy cannot establish the existence of other minds (VM 76 [GA I/ $6: 262])$. He follows this passage by giving his alternative, claiming that my sense of myself as a moral agent is necessarily a sense of myself as an individual in relation to other moral agents:

But the voice of my conscience [Gewissen] calls to me: whatever these beings may be in and for themselves, you ought to treat them as self-subsistent, free, autonomous beings completely independent of you. ... I will therefore always regard those beings as beings which exist for themselves and are there independently of me, as beings which set themselves purposes and carry them out. From this standpoint I will not be able to see them any other way, and that speculation [according to which they are mere representations] will disappear before my eyes like an empty dream. (VM 76 [GA I/6:262])

51 No theoretical argument, including the appeal to signs, can successfully demonstrate that some of my representations are representations of conscious beings. But the failure of theoretical reasoning here is irrelevant given my sense of obligation to those beings (and not those representations). My conception of others as rational beings follows from my duty to treat them as such. ${ }^{31}$

The moral feeling of considerability is not a theoretical proposition. If one asks for a set of propositions that prove that there are other morally considerable people out there, which is presupposed by the problem of other minds, trying to answer that question would already be engaging the problem in the wrong way - thus conceding too much from the beginning. The challenge is badly formulated. It assumes that the question is amenable to theoretical proof - something that Kant himself, in distinguishing appearances from the thing in itself, showed not to be the case. Fichte dispels the problem of other minds, rather than trying to solve it, by rejecting this foundational assumption and providing a separate, practical proof.

Because of the immediacy of the feeling of obligation, Fichte does not to treat this founding practical assumption as a claim to be justified. I consider other rational beings to be persons because I must do so given my ethical commitments, just as I accept idealism over dogmatism because I must do so given the kind of person I am (IWL 20 [GA I/4:195]). Retrospectively, Fichte's philosophical account of subjectivity and the summons explains or makes comprehensible why we have this relation to others (IWL 38n [GA I/4:210-11n]), but it is not meant to justify a moral feeling that is immediate and in no need of justification from the first-person, practical perspective.

\section{Conclusion: The Coherence of Fichte's View}

54 It is now commonly accepted among Fichte scholars that intersubjectivity plays a central role in his philosophy, and that the longstanding charge of subjectivism is misguided. What has been missing is an appreciation of how Fichte responds to the problem of other minds. The summons dispels metaphysical solipsism, to be sure, but establishing others' distinctively moral considerability is a result of conscience, as felt from the first-person perspective. This recapitulates his practical strategy for establishing the truth of idealism, and in that sense it is of a piece with the starting point of the Wissenschaftslehre. It is also more consistent with the fact of reason strategy by which Kant establishes my own humanity than the appeal to signs made by Engelhardt, Van Kirk, and Frierson. Although I do not have the space to defend it here, 
I believe that Fichte's view more accurately captures the phenomenology of moral experience. The metaphysical question of whether someone is in fact morally considerable is secondary to and, in a practical sense, is decided by our immediate ethical relationship with them. ${ }^{32}$

\section{NOTES}

1. I reference works by Kant and Fichte parenthetically using the following abbreviations: A/B = Kant, Critique of Pure Reason, trans. and ed. Paul Guyer and Allen W. Wood (Cambridge: Cambridge University Press, 1998).

Ak = Kant, Kants gesammelte Schriften, 29 vols., ed. Preussische Akademie der Wissenschaften (Berlin: de Gruyter, 1900- ).

An = Kant, Anthropology from a Pragmatic Point of View, trans. Robert B. Louden, in Anthropology, History, and Education, ed. Günter Zöller and Robert B. Louden, 231-429 (Cambridge: Cambridge University Press 2007).

$\mathrm{CPrR}=$ Kant, Critique of Practical Reason, in Practical Philosophy, trans. and ed. Mary J. Gregor, 137-271 (Cambridge: Cambridge University Press, 1996).

EPW = Fichte, Early Philosophical Writings, trans. Daniel Breazeale (Ithaca: Cornell University Press, 1988).

FNR = Fichte, Foundations of Natural Right, trans. Michael Baur, ed. Frederick Neuhouser (Cambridge: Cambridge University Press, 2000).

$\mathrm{G}=$ Kant, Groundwork of the Metaphysics of Morals, in Practical Philosophy, trans. and ed. Mary J. Gregor, 41-108 (Cambridge: Cambridge University Press, 1996).

GA = Fichte, J. G. Fichte - Gesamtausgabe der Bayerischen Akademie der Wissenschaften, 42 vols., ed. Reinhard Lauth et al. (Stuttgart-Bad Cannstatt: Frommann-Holzboog, 1962- ).

$\mathrm{IWL}=$ Fichte, Introductions to the Wissenschaftslehre and Other Writings, trans. and ed. Daniel Breazeale (Indianapolis: Hackett, 1994).

$\mathrm{K}=$ Fichte, Wissenschaftslehre nova methodo ("Krause Nachschrift"), ed. Erich Fuchs (Hamburg: Meiner, 1982).

LM = Kant, Lectures on Metaphysics, trans. and ed. Karl Ameriks and Steve Naragon (Cambridge: Cambridge University Press, 1997).

MM = Kant, Metaphysics of Morals, in Practical Philosophy, trans. and ed. Mary J. Gregor, 363-602 (Cambridge: Cambridge University Press, 1996).

NM = Fichte, Foundations of Transcendental Philosophy: (Wissenschaftslehre) nova methodo, trans. Daniel Breazeale (Ithaca: Cornell University Press, 1992).

RPP = Fichte, "Review of Immanuel Kant, Perpetual Peace: A Philosophical Sketch (Königsberg: Nicolovius, 1795)," trans. Daniel Breazeale, Philosophical Forum 32, no. 4 (Winter 2001): 311-21.

$\mathrm{SE}=$ Fichte, System of Ethics, trans. and ed. Daniel Breazeale and Günter Zöller (Cambridge: Cambridge University Press, 2005).

SK = Fichte, Science of Knowledge, trans. Peter Heath and John Lachs (New York: Appleton-CenturyCrofts, 1970).

VM = Fichte, Vocation of Man, trans. Peter Preuss (Indianapolis: Hackett, 1987). 
With Kant's works, I cite the volume and page number(s) of the Royal Prussian Academy edition (Ak), which are included in the margins of the translations. With Fichte references, I cite both the English translation (where applicable) and the original German as collected in GA or K.

2. Christina Hoff, “Kant's Invidious Humanism," Environmental Ethics 5, no. 1 (Spring 1983): 63-70, at 69 .

3. Jonathan Bennett, "The Simplicity of the Soul," Journal of Philosophy 64, no. 20 (Oct. 1967): 648-60, at 655. Regarding what he calls Kant's "methodological solipsism," Bennett's idea is that any knowledge that I have about the world can only be validated by evidence and intuitions that I have. Any knowledge claims are subjective in that sense. This makes the problem of other minds particularly difficult for Kant. See also Jonathan Bennett, Kant's Analytic (Cambridge: Cambridge University Press, 1966), 126-30.

4. Patrick R. Frierson, Kant's Empirical Psychology (Cambridge: Cambridge University Press, 2014), 167-88.

5. H. Tristram Engelhardt, Jr., "Kantian Knowledge of Other Persons - An Exploration," in Akten des 4. Internationalen Kant-Kongresses Mainz 1974, ed. Gerhard Funke, vol. 2, no. 2 (Berlin: de Gruyter, 1974), 576-81, at 580.

6. Ibid., 579.

7. Carol A. Van Kirk, "Kant and the Problem of Other Minds," Kant-Studien 77, no. 1 (1986): 41-58, at 54-55.

8. Ibid., 57.

9. Frierson, Kant's Empirical Psychology, 171.

10. Ibid., 172, 185.

11. Engelhardt, "Kantian Knowledge of Other Persons," 579.

12. See Matthew C. Altman, "Idealism Is the Only Possible Philosophy: Systematicity and the Fichtean Fact of Reason," Idealistic Studies 31, no. 1 (Winter 2001): 1-30.

13. Jean Paul, Clavis Fichtiana seu Leibgeberiana (1799), in Sämmtliche Werke (Berlin: Reimer, 1827), 30:44, 47.

14. Fichte's "formal freedom" roughly corresponds to Kant's use of Willkür as the capacity for free choice (practical freedom in the negative sense) (G 4:446; CPrR 5:33; MM 6:213-14), coupled with the notion that willing is an uncaused cause (transcendental or cosmological freedom) (A533/B561, A803/B831; CPrR 5:3, 29, 96-97). Fichte's "material freedom" is Kant's Wille, or the capacity to act autonomously on the basis of a law that one gives oneself (practical freedom in the positive sense) (G 4:446-47; CPrR 5:33; MM 6:213-14).

15. Allen W. Wood, "Deduction of the Summons and the Existence of Other Rational Beings," in Fichte's "Foundations of Natural Right": A Critical Guide, ed. Gabriel Gottlieb (Cambridge: Cambridge University Press, 2016), 72-91, at 83.

16. This is the point at which Fichte comes closest to Kant's approach to the problem of other minds, and specifically Engelhardt's interpretation. The subjectivity of the other is a condition for the possibility of such behavior only if we assume that the behavior could only be explained with reference to reason. This begs the question, or at least seems to.

17. Whether Kant derives the universal principle of right from the categorical imperative, as Fichte claims (RPP 314-15 [GA I/3:220-21]), is a matter of scholarly disagreement. Arguments for their independence are given in, e.g., Allen Wood, "The Final Form of Kant's Practical Philosophy," in Kant's "Metaphysics of Morals": Interpretive Essays, ed. Mark Timmons (Oxford: Oxford University Press, 2002), 1-22; and Marcus Willaschek, "Right and Coercion: Can Kant's Conception of Right Be Derived from His Moral Theory?" International Journal of Philosophical Studies 17, no. 1 (2009): 49-70. Arguments for their dependence are given in, e.g., Paul Guyer, "Kant's Deductions of the Principles of Right," in Kant's "Metaphysics of Morals": Interpretive Essays, ed. Mark Timmons (Oxford: Oxford University Press, 2002), 23-64; and Gerhard Seel, "How Does 
Kant Justify the Universal Objective Validity of the Law of Right?" International Journal of Philosophical Studies 17, no. 1 (2009): 71-94.

18. Angelica Nuzzo, "The Role of the Human Body in Fichte's Grundlage des Naturrechts (1796-97)," in Rights, Bodies, and Recognition: New Essays on Fichte's "Foundations of Natural Right," ed. Dan Breazeale and Tom Rockmore (Aldershot, Burlington: Ashgate, 2006), 71-89, at 74.

19. I am indebted to Steven Hoeltzel for helpful suggestions on how to frame some of the claims discussed in this section.

20. Stephen Darwall, "Fichte and the Second-Person Standpoint," in Honor, History, and Relationship: Essays in Second-Personal Ethics II (Oxford: Oxford University Press, 2013), 222-46; Robert R. Williams, "The Question of the Other in Fichte's Thought," in Fichte: Historical Contexts/ Contemporary Controversies, ed. Daniel Breazeale and Tom Rockmore (Atlantic Highlands, N.J.: Humanities, 1994), 142-57; and Robert R. Williams, Hegel's Ethics of Recognition (Berkeley: University of California Press,1997), 31-39.

21. Darwall, "Fichte and the Second-Person Standpoint," 241-45.

22. Williams, "Question of the Other in Fichte's Thought," 155; and Williams, Hegel's Ethics of Recognition, 38. Other comparisons of Fichte and Levinas on the question of the other include Simon Lumsden, "Absolute Difference and Social Ontology: Levinas Face to Face with Buber and Fichte," Human Studies 23, no. 3 (July 2000): 227-41; Scott Scribner, "Levinas Face to Face with Fichte," Southwest Philosophy Review 16, no. 1 (Jan. 2000): 151-60; and Ives Radrizzani, "The Self, the Other and the Limit by Fichte and Levinas," Archives de Philosophie 73, no. 2 (April-June 2010): 285-95.

23. For example: "This summons [sommation] to responsibility destroys the formulas of generality by which my knowledge (savoir) or acquaintance (connaissance) of the other man re-presents him to me as my fellow man" (Emmanuel Levinas, "Ethics as First Philosophy," in The Levinas Reader, ed. Seán Hand [Oxford: Blackwell, 1989], 84).

24. In his 1793 defense of the French Revolution, Beitrag zur Berichtigung der Urtheile des Publikums über die französische Revolution (GA I/1:203-404), Fichte argues that individuals need to be free in order to realize their moral autonomy and fulfill their moral duties. The public recognition of natural rights and coercion designed to protect them are necessary to further morality. Thus Fichte derives his nascent political theory from the moral law. He reverses that position by 1796 .

25. Daniel Breazeale, “The First-Person Standpoint of Fichte's Ethics," Philosophy Today 52, nos. 3-4 (Fall-Winter 2008): 270-81; and Frederick Neuhouser, "Fichte's Separation of Right from Morality," in Fichte's "Foundations of Natural Right": A Critical Guide, ed. Gabriel Gottlieb (Cambridge: Cambridge University Press, 2016), 32-51. See also Nedim Nomer, "Fichte's Separation Thesis," Philosophical Forum 44, no. 3 (Fall 2013): 233-54.

26. Wood, Fichte's Ethical Thought, 95-96.

27. Charles W. Mills, Blackness Visible: Essays on Philosophy and Race (Ithaca: Cornell University Press, 1998), 8-10, 152-66.

28. In a parenthetical comment, Fichte notes a similar thought in Schelling's Neue Deduction des Naturrechts (1796/97): "Where my moral power encounters resistance, there can no longer be nature. I shudder and stop. I hear the warning: here is humanity! I am not permitted to proceed any farther" (SE 213 [GA I/5:204]).

29. Allen W. Wood, "Fichte's Philosophy of Right and Ethics," in The Cambridge Companion to Fichte, ed. David James and Günter Zöller (Cambridge: Cambridge University Press, 2016), 168-98, at 190.

30. This, and not the summons, is much closer to Levinas than Williams realizes. Levinas claims that the immediate encounter with the face of the other imposes obligations prior to any recognition that the other is like me. The other is not an alter ego, whose moral status rests on her interchangeability with the self/I. Instead, my indebtedness to the other precedes any judgment as to the kind of thing they are. See especially Emmanuel Levinas, Otherwise Than Being; or Beyond Essence, trans. Alphonso Lingis (Pittsburgh: Duquesne University Press, 1997), 159. 
31. One of the problems masked by Fichte's appeal to the "voice of conscience" is the contingency of moral feeling. There is little recognition of the social conditions of moral considerability. According to critical race theory, I derive the substance of what my conscience says from the moral models around me, not from pure reason. Fichte does anticipate the spirit of this with his doctrine of the summons: the I is affected by a community before belief in the community is philosophically established.

32. I am indebted to Cynthia D. Coe and Kienhow Goh for reading drafts and suggesting promising directions for this essay.

\section{ABSTRACTS}

The present paper examines the problem of attributing mental predicates to anyone but myself. Traditionally, this has been a major issue at the intersection of epistemology and ethics, because whether we should consider someone in our moral deliberations is often thought to depend on their cognitive abilities or their capacity for consciousness. For both Kant and Fichte, we have direct moral duties only to other rational beings. The fact that the other is present to us as a representation (for Kant) or as a Not-I that is posited in opposition to the I (for Fichte) threatens our supposed moral obligations to them and risks a form of metaphysical solipsism and moral egoism. The bindingness of interpersonal obligations depends on overcoming the separation between me and other persons. It will be shown that in order to establish the other as a morally considerable being, Fichte reverses the direction of implication: I do not derive my moral duties from others' personhood; rather, others' personhood follows from my immediate sense of moral obligation toward them. The way that the problem of other minds is posed presupposes that the only appropriate answer would be a series of propositions that establishes the existence of other morally considerable beings outside of myself. The immediate moral feeling of considerability, however, is not a proposition. It will be argued that Fichte thus provides a radically different alternative to Kant's approach. The problem of other minds is not answered or solved but is rather dispelled in Fichte's philosophy by the feeling of moral obligation and the recognition of others as the object of our obligations.

\section{INDEX}

Keywords: intersubjectivity, recognition, solipsism, problem of other minds

\section{AUTHOR}

\section{MATTHEW C. ALTMAN}

Central Washington University 